\title{
An Examination of Academic Studies Covering Israel Palestine Conflict Over its Reflections Through Media
}

\section{Murat Sahin, Anadolu University, Turkey}

\begin{abstract}
The media plays an important role in during the periods of wars and conflicts. The media ensures public knowledge of the events by carrying the messages to the masses in these periods. The contents of media messages usually cause the public to develop certain views and feeings about the war and the conflict. The long-term and still ongoing conflict between Israel and Palestine today are still among the most long-lasting conflicts. Events and representations regarding this conflict are also reflected in the contents of various media. The mentioned conflict has became subject to a remarkable number of academic studies. This paper examines academic studies covering Israeli-Palestine conflict through its reflections on various media. Within this context, a total number of 50 academic studies were analyzed. Of these studies, 25 were about newspapers, 16 were about television, 6 were about both television and newspapers, 2 were about movies and 1 was about magazines. The contents of these studies were examined in terms of the most focused issues, types of mass media, ideological and their emerging results.
\end{abstract}

Keywords: War, Conflict, Media, Israel Palestinian Conflict. 


\section{Introduction}

The media plays an important role in during the periods of wars and conflicts. The media ensures public knowledge of the events by carrying the messages to the masses in these periods. Especially, the importance of the media further increases in long term conflict. Because, it is important to have information about their condition both inside the public as well as world public opinion. The media are important as a place the attack on the grounds that the production and victimization shown for the parties to the conflict.

The long term and still ongoing conflict between Israel and Palestine today are still among the most long-lasting conflicts. With a long historical background, conflict between Israel and Palestine still continues today. This conflict dates back to the ancient history of the Middle East (Armaoğlu, 1994).Conflicts between Israel and Palestine have further increased as from early $20^{\text {th }}$ century. Conflicts have ever been present in the region especially after 1948, the foundation year of Israel. Conflicts between the two societies can mainly be grouped as the war of 1948, the war of 1967, First Intifada, Second Intifada and Gaze wars (Süer and Atmaca, 2006).

\section{Methodology}

This study was conducted on the basis of general survey model. Researches in general survey model are for describing the situation as it is as regards the subject matter handled(Karasar, 2010: 79). In this study, general survey model was used since it was tried to reveal out the present situation through a general assessment of academic studies dealing with how the conflicts between Israel and Palestine were reflected in the media.

50 academic studies in total could be reached within the scope of this study. Classification of academic studies dealing with reflection of conflicts between Israel and Palestine in the media was again provided through such academic studies handled. According to this, studies were collected under 6 event titles such as "First Intifada, Second Intifada, First and Second Intifada, Gaze Attacks, 11 September attacks and Nakba." 50 academic studies handled in this research were analysed on the basis of aspects with respect to event and period, media type, country media, distribution of studies by newspapers and televisions and the type of publication. Further the results emerged as a result of these studies were mentioned generally. 
The studies subject to analysis were reached from the Library of Anadolu University as printed and e-sources.

\section{Results}

Table 1. Distribution of Studies by Subjects

\begin{tabular}{lc}
\hline Subjects & Number \\
\hline First Intifada & 14 \\
\hline Second Intifada & 21 \\
\hline First and Second Intifada & 3 \\
\hline Gaze Attacks & 6 \\
\hline 11 September Attacks & 4 \\
\hline Nakba & 2 \\
\hline Total & $\mathbf{5 0}$ \\
\hline
\end{tabular}

Distribution of studies dealing with reflection of conflicts between Israel and Palestine by subjects in media was presented in Table 1. According to this; 14 out of 50 academic studies reached consist of First Intifada, 21 of such consist of studies dealing with aspect of reflection to media of Second Intifada, 3 of such consist of First and Second Intifada, 6 of such consist of Gaze Attacks, 4 of such consist of 11 September Attacks and finally 2 of such academic studies consist of Nakba.

Table 2. Distribution of Studies by Publication Type

\begin{tabular}{lc}
\hline Publication Type & Number \\
\hline Books & 8 \\
\hline Chapters in the boks & 13 \\
\hline Articles & 28 \\
\hline Phd thesis. & 1 \\
Total & $\mathbf{5 0}$ \\
\hline
\end{tabular}

Distribution of studies dealing with reflection of conflicts between Israel and Palestine by publication type in media was presented in Table 2 . According to this; 8 out of 50 academic 
studies reached consist of books, 13 of such consist of chapters in the books, 28 of such consist of articles and 1 of such consist of Phd thesis.

Table 3. Distribution of Studies by Media Type

\begin{tabular}{lc}
\hline Media Type & Number \\
\hline Newspaper & 25 \\
\hline Television & 16 \\
\hline Both Newspaper and television & 6 \\
\hline Magazine & 1 \\
\hline Films & 2 \\
\hline Total & $\mathbf{5 0}$ \\
\hline
\end{tabular}

Distribution of studies dealing with reflection of conflicts between Israel and Palestine by media type in media was presented in Table 3. According to this; 25 out of 50 academic studies reached consist of newspaper, 16 of such consist of television, 6 of such consist of both newspaper and television, 1 of such consist of magazine and 2 of such consist of films.

Table 4.Distribution of Studies by Country media

\begin{tabular}{lc}
\hline Country & Number \\
\hline USA & 18 \\
\hline Israel & 16 \\
\hline USA, Israel & 3 \\
\hline England & 4 \\
\hline Arabic & 2 \\
\hline USA, Israel, England, Germany & 1 \\
\hline USA, Israel, England, Arabic & 1 \\
\hline Israel, Palestine & 1 \\
\hline Dutch & 2 \\
\hline Palestine Cinema & 2 \\
\hline Total & $\mathbf{5 0}$ \\
\hline
\end{tabular}


Distribution of studies dealing with reflection of conflicts between Israel and Palestine by country media in media was presented in Table 4. According to this; the majority of the academic studies reached 50 consist of USA and Israel media. There also studies about British, Dutch and Palestine media.

\section{First Intifada}

There are 14 academic studies analysing reflection of First Intifada to the media. 3, 5, and 6 of these studies are books; chapters in the books and articles respectively. Newspapers are handled in 7 studies and televisions are handled in other 7 of the studies. As to the distribution of studies by country media, there are 5 studies on the media of USA, 8 studies on the media of Israel and 1 study on the media of USA, Israel, England and Germany. While the newspapers which were taken as sample in the academic studies on the reflection of First Intifada in the media and which were mostly reviewed were Yediot Ahronot and Ha'aretz from Israel media, such were The Washington Post and The New York Times newspapers from American Media. Still the televisions analysed as regards this period were Mabat and Chadashot televisions from Israel media.

According to the results reached by the studies; Israeli media's attitude towards the First Intifada was in a way to "trivialize, delegitimize the intifada and define it such as events that took place with the support of foreign powers." Israel media pursued a policy not to mention much about the events and Palestinians in their news (First, 1998). Besides, the press of Israel became an area where dominant ideology was reproduced thereby declaring mobilization in crisis periods and leaving aside policies of journalism to enlighten the public. Newspapers and televisions deemed the events of intifada in terms of national interests (Wolfsfeld, 1997). Attitude of American press towards the events in the First Intifada; unlike the relatios of America and Israeli, news about intifada had a wide coverage in American media (Liebes, 1992). The attitude of American press in the First Intifada had a significant role on taking the attention of world opinion towards the claims of Palestinians (Wolfsfeld, 1997).

The role of media in the First Intifada: Generally speaking Palestine found place in world opinion thanks to the First Intifada. The world had an opportunity to see the situation and lives of Palestinians. As for Israel, it was stuck in a difficult situation in front of world opinion. 


\section{Second Intifada}

There are 21 academic studies analysing reflection of Second Intifada to the media. 4, 4, 12 and 1 of these studies are books, chapters in the books, articles and phd thesis respectively. Newspapers are handled in 11 studies, televisions are handled in 4 of the studies and both newspaper and televisions are handled in 6 of the studies. As to the distribution of studies by country media, there are 7 studies on the media of USA, 6 studies on the media of Israel and 3 studies on the media of England.Also, there are 1 studies on the media of Arabic, 2 studies on the media of USA, Israel, 1 study on the media of Israel, Palestine and 1 study on the media of USA, England, Israel, Palestine. While the newspapers which were taken as sample in the academic studies on the reflection of Second Intifada in the media and which were mostly reviewed were YediotAhronot, Ma'ariv, Ha'aretz, TheJerusalemPost, TheNewYorkTimes, The Guardian, The Observer and The Independent. Still the televisions analysed as regards this period were $N B C T V, B B C$, ITV and Aljazeera.According to the results reached by the reviewed study; attitude of the media in Israel towards Second Intifada was generally to move ahead in accordance with mobilization which is as usual in every conflict period. Israeli media in these periods reproduces the differences between Israel and Palestine. Reflecting that the struggle of Israel to be against terrorism, Israeli press has a tendency to associate Palestinians with terrorism (Korn, 2004a; Korn, 2005; Rinnawi, 2007). Furthermore, the editors in Israeli press in these conflict periods prepared the news in accordance with broadcasting policies and national interests but not in company with the information reported by pressmen (Dor, 2004). As to the attitude of American press to the events in the Second Intifada was from the perspective of Israel. Associating Palestinians with terrorism, American press present the attack of Israel against Palestinians as a struggle against terrorism (Friel and Falk, 2007; İsmail, 2008; Elmasry, 2009). As to Arabic media (Aljazeera), pursued a news policy in favour of Palestine (Zayani, 2005).

Unlike the First Intifada, America and Israel pursued a joint news policy as regards the intifada in the Second Intifada. American and Israeli media saw the events from the perspective of Israel, they had an inclination to condemn the deaths caused by Palestinians and they presented Palestinians as cruel and offensive while legitimizing the deaths caused by Israel, justifying such deaths and presenting Israeli people as sufferers. As for American press, they present the attack of Israel against Palestine as a struggle against terrorism thereby associating Palestinians with terrorism. 


\section{First and Second Intifada}

There are 3 academic studies analysing reflection of First and Second Intifada together to the media. All of these studies are articles and newspapers are handled in this studies. As to the distribution of studies by country media, there are 2 studies on the media of Dutch and 1 study on the media of USA, Israeli. According to the results obtained from the studies; while the image of Palestine in the First Intifada was favourable and the image of Israel was unfavourable according to the results reached by Deprez and Raeymaeckers $(2010 ; 2011)$ who analysed the presentation of First and Second Intifada in Flemish newspapers in two separate studies, completely contrary results were obtained in the Second Intifada; the image of Israel become favourable and the image of Palestine became unfavourable. As for Matt Viser (2003), he concluded that the media of both countries pursued a broadcasting policy in favour of Israel during the First and Second Intifada in his study on American and Israeli press.

\section{Gaze Attacks}

There are 6 academic studies analysing reflection of Gaze attacks to the media. 1 and 5 of these studies are books and articles respectively. Newspapers are handled in 2 studies and televisions are handled in other 4 of the studies. As to the distribution of studies by Gaze attacks, there are studies about the media of USA, Israel, England and Arabic. While the newspapers which were taken as sample in the academic studies on the reflection of Gaze attacks in the media and which were mostly reviewed were The Jerusalem Post, The New York Times and Washington Post.Still the televisions analysed as regards this period were BBC, ITV, Channel 4, Al-Jazeera and Al-Arabiya. According to the results reached by the studies reviewed; the studies conducted include American, Israeli, British and Arabic media. It was concluded that Arabic media (Aljazeera and AlArabiya) pursued a news policy in favour of Palestine (Elmasry et al., 2013) whereas the British media pursued a broadcasting policy in favour of Israel (Thomas, 2011).

\section{September Attacks}

There are 4 academic studies analysing reflection of after 11 September attacks to the media. 2 and 2 of these studies are chapters in the books and articles respectively. Newspapers are handled in 2 studies, televisions are handled in 2 of the studies and magazine is handled in 1 studies. As to the distribution of studies by after 11 September attacks, there are studies about 
the media of USA. The study on magazine is about Time magazine. While the newspapers and magazine which were taken as sample in the academic studies on the reflection of after 11 September attacks in the media and which were mostly reviewed were The New York Times and Time magazine.Studies on the representation of Arabs and Palestinians in particular, in the media were conducted especially after 11 September attacks. Perspective of American media on the conflict between Israel and Palestine is not independent of Middle East policy of America. Therefore, American press indicates Palestinians as aggressive, terrorist, bad man and Israeli people as sufferers (Ross, 2003a; 2003b).

\section{Nakba}

There are 2 academic studies analysing reflection of Nakba to the media. This studies are about films. Both studies aimed to determine how the Nakba represented in cinema (Bresheeth, 2007; Yaqub, 2013).

\section{Conclusion}

It was carried out in this study, a general assessment of academic studies dealing with the reflection in the media of the conflict between Israel and Palestine on the basis of survey model. To this end, assessment of 50 academic studies reached were made in several categories. According to the results of the study; most of the studies were conducted about the First (14) and Second Intifada (21). As regards the type of publication, chapters in the book (13) and articles (28) are at the forefront. As for the type of media; newspapers (25) and televisions (16) were focused on. As to the distribution of studies by the media of country, the media of USA (18) and the media of Israel (16) comprise the most of the studies.

Another reason obtained from the studies is that while the Palestinians were reflected as sufferer and right and Israeli people as offensive and unfair in the First Intifada in the reflection of conflicts between Israel and Palestine in the media; Palestinians were reflected as terrorists or as those who are associated with terrorism and the Israeli people were reflected as sufferer and as those who have a struggle with terrorism in all other conflict periods. Besides, Israeli press has an inclination to make news of the events in accordance with national interests beyond reality thereby declaring mobilization in the periods of conflict. As to the press in USA, it maintained its news policy coordinated with the policy of 
Online Journal of Communication and Media Technologies

Volume: 7 - Issue: 1 January - 2017

country. All in all, it can be said that media is affected by several events in the periods of war and conflict while reporting the incidents to the public. 


\section{References}

Armaoğlu, F. (1994). Filistin Meselesi ve Arap-İsrail Savaşları (1948-1988). Ankara: Türkiye İş Bankası Kültür Yayınları.

Karasar, N. (2010). Bilimsel Araştırma Yöntemi. Ankara: Nobel Yayın.

Süer, B. ve Atmaca, A.Ö. (2006). Arap-İsrail Uyuşmazlı̆̆ı. Ankara: ODTÜ Yayıncılık.

\section{Academic Studies}

Aqtash N. A., Seif. A. and Seif. A. (2004). Media coverage of Palestinian children and the Intifada. Gazette 66(5): 383-409.

Amer, M.M. (2009). Telling-it-like-it-is: The Delegitimation of the Second PalestinianIntifada. İn Thomas Friedman's Discourse', Discourse Society 20 (1): 531.

Barkho, L. (2008). The BBC's Discursive Strategy and practices vis-a vis thePalestinian and Israeli conflict. Journalism Studies, 9(2): 278-294.

Bresheeth, H. (2007). The continuity of trauma and struggle: Recent cinematic represantations of the Nakba. (Eds. Ahmad S. and Lila A.). Nakba: Palestine, 1948, and the claims of memory. New York: Columbia Uni. Press.

Cohen, A. A., H. Adoni and H. Nossek (1993) 'Television News and the Intifada: A Comparative Study of Social Conflict', in A. A. Cohen, and G. Wolfsfeld (eds) Framing the Intifada: People and Media, pp. 116-41. Norwood, NJ: Ablex.

Daniels, A. (1995). US Media Coverage of the Intifada and American Public Opinion, 62-71 in Y. Kamalipour (ed.) US Media and the Middle East: Image and Perception. Westport, Greenwood

Deprez, A. and Raeymaeckers, K. (2010). Bias in the news? The representation of Palestinians and Israelis in the coverage of the First and Second Intifada. International Communication Gazette 72(1): 91-109.

Deprez, A. and Raeymaeckers, K. (2011). Bottlenecks in the coverage of the IsraeliPalestinian conflict: the coverage of the first and second intifada in the Flemish press. Media, War \& Conflict. 4(2) 185-202.

Dor, D. (2004) Intifada Hits the Headlines: How the Israeli Press Misreported the Outbreak of the Second Palestinian Uprising. USA: Indiana University Press.

Dunsky, M. (2008). Pens and swords: How the American mainstream media report the Israeli-Palestinian conflict. New York: Columbia University Press. 
Elmasry, M. H. (2009). Death in the Middle East: An analysis of how the New York Times and Chicago Tribune framed killings inthe second Palestinian intifada. Journal ofMiddle EastMedia 5(1):1.46.

Elmasry, M. H., Shamy, A. E., Manning, P., Mills, M. and Auter, P. J. (2013). Al-Jazeera and Al-Arabiya framing of the Israel-Palestine conflict during war and and calm periods. International Communication Gazette, 75(8) 750-768.

Enderlin, C. (2003) 'Enemies of Israel: The Foreign Press and the Second Intifada', Palestine-IsraelJournal 10(2): 17-22.

First, A. (1998). Who is the enemy? The portrayal of Arabs in Israeli television news. Gazette: The International Journal for Communication Studies. 60(3): 239-251.

First, A. (2012). The Fluid Nature of Representation Transformations in the Representation of Arabs in Israeli Television News Howard Journal of Communications, Volume 13, Number 2, pp. 173- 190(18),

Friel, H.,\& Falk, R. (2007). Israel-Palestine on record How the New York Times misreports conflict in the Middle East. London and New York: Verso.

Handley, R. L. (2009). The conflicting Israeli-terrorist image: Managing the IsraeliPalestinian narrative in the New York Times and Washington Post. Journalism Practice 3(3), 251-267.

Handley, R.L. and Ismail, A. (2010). Territory under siege: 'Their' news, 'our' news and 'ours both' news of the 2008 Gaza crisis. Media, War and Conflict. 3(3): 279-297.

Ibrahim, D. "The Middle East in American News: A 20th Century Overview" InternationalCommunication Gazette. Vol. 71, No. 6, October 2009.

İsmail, A. (2008). Mission statehood: portraits of the second Palestinian intifada in US news media. Media, War \& Conflict. 1(2): 177-201.

Kandil, M.A. (2009). The Israeli-Palestinian conflict in American, Arab and British media: Corpus-based critical discourse analysis. Applied Linguistics and English as a Second Language Dissertations.

Korn, A. (2004a). Israeli Press and the War against Terrorism: The Construction of the 'Liquidation Policy'. Crime, Law \& Social Change, 41(3): 209-234.

Korn, A. (2004b). Reporting Palestinian Casualties in the Israeli Press: The Case of Haaretz and the Intifada. Journalism Studies. 5(2): 247-62. 
Korn, A. (2005). Joined Forces: The IDF and the Israeli Press Reporting of the Intifada. In E. Poole \& J. E. Richardson (eds.), Muslims and the News Media(pp. 142- 152). London: I.B. Tauris.

Lederman, J. (1992). Battle Lines The American Media and the Intifada. New York: Henry Holt.

Liebes, T. (1992) 'Our WarTheir War Comparing the Intifadeh and the Gulf War on U.S. and Israeli Television', Critical Studies in Mass Communication 9(1) 44.55.

Liebes, T. and Kampf, Z. (2009). Black and white and shades of gray: Palestinians in the Israeli media during the 2nd intifada. International Journal of Press/Politics. 14(4): 434-453.

Liebes, T., and A. First. 2003. "Framing the Palestinian-Israeli Conflict." In Framing Terrorism: The News Media, the Governments and the Public, ed. P. Norris, M. Kern, and M. Just, 59-74. New York: Routledge.

Loshitzky, Y. (1993). Ways of Seeing the Intifada: The Case of Nahalin. In A. Cohen \& G. Wolfsfeld (Eds.), Framing the Intifada: People and media(pp. 142-159). Norwood, NJ: Ablex.

Philo, G. (2012). Pictures and public relations in the Israeli-Palestinian conflict. In: Freedman, D. and Thusso. D.K. (eds) Media and Terrorism: Global Perspectives. London: Sage. 151-164.

Philo, G., A. Gilmour, S. Rust, E. Gaskell, M. Gilmour and L. West ( 2003) 'The IsraeliPalestinian Conflict: TV News and Public Understanding', pp. 133-48 in D.K. Thussu and D. Freedman (eds) War and the Media. London: Sage.

Philo, G. and Berry, M. (2004). Bad News from Israel. London: Pluto Press.

Richardson, J.E. and Barkho, L. (2009). Reporting Israel/Palestine: Ethnographic insights into the verbal and visual rhetoric of BBC journalism. Journalism Studies 10(5): 594622.

Rinnawi, K. ( 2007). De-legitimization of media mechanisms: Israeli press coverage of the Al Aqsa intifada. Gazette: The International Journal for Communication Studies 69(2): 149-178.

Roeh, Y. ve Nir, R. (1990). Covering the intifada in the Israeli press: Popular and quality papers assume rhetoric of conformity. Discourse and Society. 3, 22-36 
Roeh, I. and R. Nir. (1993). Reporting the Intifada in the Israeli Press: How Mainstream Ideology Overrides "Quality" and "Melodrama", pp. 92-118 in A.A. Cohen and A. Wolfsfeld (eds) Framing the Intifada People and Media. Norwood, NJ: Ablex

Ross, S.D. (2003a). Framing of the Palestinian-Israeli conflict in thirteenmonths of NewYork Times editorials surrounding the attackof September 11 2001. Conflict and Communication Online 2(2).

Ross, S.D. (2003b). Unequal combatants on an uneven media battlefield: Palestine and Israel.

In: Lester P. M, Dente R. S. Images that Injure: Pictorial Stereotypes in the Media. CT: Praeger, 58-63.

Ross, S. D. and Bantimaroudis, P. (2006). Frame Shifts and Catastrophic Events: The Attacks of September 11, 2001, and New York Times's Portrayals of Arafat and Sharon.Mass Communication and Society. 9(1), 85-101.

Roy, S. (2012). Culturally unconscious: Intercultural implications of The New York Times representation of the Israel-Palestine conflict in 2009 and 2011. International Communication Gazette, 74(6) 556-570.

Slater, J. (2007) 'Muting the Alarm over the Israeli-Palestinian Conflict: The New York Times versus Haaretz, 2000-2006', International Security 32(1): 84-120.

Thomas, L. (2011). Reconstructions of 'reality'? The coverage of the Gaza withdrawal in the British media. Journalism Studies 12(4): 522-538.

Tidhar, C.,\& Lemish, D. (1993). Women in the Intifada: A television news perspective. In A. Cohen \&G. Wolfsfeld (Eds.), Framing the Intifada: People and media 142-159). Norwood, NJ: Ablex.

Viser, M. (2003). Attempted objectivity: An analysis of the New York Times and Ha'aretz and their portrayals of the Palestinian-Israeli conflict. Harvard International Journal of Press/Politics 8(4): 114-120.

Wolfsfeld, G. (1997). Media and Political Conflict News from the Middle East. New York: Cambridge Universty Press.

Wolfsfeld, G. Frosh, P. and Awabdy, M.T. (2008). Covering death in conflicts: Coverage of the second intifada on Israeli and Palestinian television. Journal of Peace Research 45(3): 401-417.

Zayani, M. (2005). Witnessing the Intifada Al Jazeera's coverage of the Palestinian-Israeli conflict. (Eds. Muhammed Zayani). The Al Jazeera Phenomeon: Critical Perspectives on New Arab Media. London: pluto Press. 
Zaharna, R.S. (1995). 'The Palestinian Leadership and the American media: Charging image, conflicting results', pp. 37-49 in Y. Kamalipour (ed.) US Media and the Middle East: Image and Perception. Westport, CT: Greenwood Press.

Yaqub, N. (2013). Narrating the Nakba: Palestinian Filmmakers revisit 1948. (Eds. Dina M. and Zahera H.)Narrating Conflict in the Middle East: Discourse, Image and Communications Practices in Lebanon and Palestine. New York: Library of Congress. 225-247.

Williams, C. A. (1981). Television Coverage of the Middle East. Adams, W. Norwood, N.J.:Ablex. 